\title{
Inguinal Exploration for the Management of Impalpable Undescended Testes
}

\author{
Thapa B', Pun MS²
}

\begin{abstract}
Introduction: The primary goal of surgical intervention with an impalpable testis is to locate and reposition the gonad. There has been much debate in the management of impalpable undescended testes. Many centres still advocate the role of open inguinal exploration in impalpable testes. Materials and methods: This retrospective study included 35 male patients. The clinical notes were reviewed for details of age at operation, side, location and condition of testes intraoperatively and the type of operation performed. Standard approach of inguinal explorations was performed under general anaesthesia. Follow up in first week and after 3 months was done. Results: 25(71.42\%) impalpable testes were in left side, $9(25.71 \%)$ were on right side and $1(2.85 \%)$ was bilateral. At exploration $17(47.22 \%)$ were intracanalicular, nine (25\%) were intraabdominal with seven low and two high,49(11.11\%) were scrotal and six (16.66\%) were absent, seven (41.17\%) canalicular testes underwent orchidopexy and 10(58.22\%) underwent gonadectomy for atrophied testes. Seven (77.77\%) low abdominal testes were brought down to scrotum and two $(22.22 \%)$ high abdominal were brought down to lower inguinal area as a first stage surgery. All 4(100\%) scrotal testes were atrophied and gonadectomy performed. Six patients were diagnosed anorchia, $14(87.5 \%)$ of impalpable testes that underwent orchidopexy were in a follow up with excellent results. One high first stage orchidopexy and another canalicular testes were found to have atrophied who did orchidectomy in follow-up. Conclusion: Inguinal exploration is a safe, reliable and successful surgical procedure for the management of impalpable testes including intraabdominal testes without procedure related complications.
\end{abstract}

Key words: Impalpable testes, Orchidopexy

\section{Introduction}

U ndescended testis is the most common genital anomaly in male children, having an incidence of 1 to $3 \%$ in full-term and $30 \%$ in premature new-borns. Undescended testes are commonly categorized as either palpable or impalpable. The majority of undescendent testes are easily palpable lying along the normal pathway of descent
${ }^{1}$ Dr. Bijay Thapa, MBBS, MS, Associate Professor and Senior Consultant Paediatric Surgeon, ${ }^{2} \mathrm{Dr}$. Madhusudan Pun, MBBS, MS, Head of Department and Senior Consultant Paediatric Surgeon. Both from the department of Paediatric Surgery, Kanti Children's Hospital, Maharajgunj, Kathmandu, Nepal.

\section{Address for correspondence \\ Dr. Bijay Thapa, Associate Professor \\ Department of Paediatric Surgery \\ Kanti Children's Hospital, Maharajgunj \\ Kathmandu, Nepal \\ Tel No; +977-9851029644 \\ E-mail: bijaytapa@hotmail.com}

\section{Acknowledgements: None Funding: Nil \\ Conflict of Interest: None \\ Permission from IRB: Yes}

\section{How to cite}

Thapa B, Pun MS. Inguinal Exploration for the Management of Impalpable Undescended Testes. J Nepal Paediatr Soc 2017;37(1):3640.

doi:http://dx.doi.org/10.3126/jnps.v37i1.16917

This work is licensed under a Creative Commons Attribution 3.0 License. 
or ectopically in the groin or perineum. About $20 \%$ of undescended testes are impalpable. Testes are impalpable when they are intracanalicular or intraabdominal and fail to emerge through the external ring, or when they are atrophic, dysgenetic, or absent ${ }^{1,2,3}$.

All undescended testes should be brought to the scrotum as soon as possible preferably before the age of two years so as to reduce the increased risk of complications such as loss of potential for fertility and because retained testes constitute a significant risk to the patient from mortality secondary to malignant degeneration. It is generally accepted that a patient with an undescended testes has approximately a 40-fold increase in the incidence of malignant degeneration of the testicle when compared with a patient with normal testicular descent. Therefore, if inguinal exploration does not reveal an impalpable testis, retroperitoneal and/or intraperitoneal exploration is advisable $e^{6,7,8}$.

Although a lot of international studies regarding the surgical management of impalpable testes, there are no guidelines. The management of the impalpable undescended testes remains variable depending on available facilities and can be very challenging. Laparoscopy has been used routinely in many centres for the diagnosis and management of impalpable testes $^{9,10,11}$.

The aim of our study was to analyse the outcome of trans-inguinal exploration in the management of the clinically impalpable testes in a tertiary centre from a developing country.

\section{Materials and Methods}

The medical records of 201 patients seen with undescended testes over a 40 months period (January 10, 2013 to May 10 2016) in Kanti children's hospital and BP Smriti hospital were retrospectively reviewed. Among them $35(17 \%)$ had impalpable testes. An impalpable testis was defined as one that could not be palpated using a standard technique of clinical examination. The diagnosis of impalpalpable testis was confirmed by examining the patient under general anaesthesia. Sometimes, genital ultra-sonogram aided the diagnosis. Patients with sexual ambiguity and those palpable cases after general anaesthesia were not included. All the clinical notes were reviewed for details of age, side of undescended testis, location and condition of testes intraoperatively and the type of operation performed. Post-operatively, children received oral antibiotic and analgesic and discharged on the same day or the first post op day. Follow-up examination after surgery was conducted in a week and three months' time. After that, one follow-up in six-to one-year was advised.

During the exploration, if the testis was not found in the inguinal canal or by following a hernia sac to the internal ring, a retroperitoneal and intraperitoneal exploration is carried out through the deep ring lateral to the inferior epigastric vessels and limited laparotomy was performed. In both approaches, the viable testis is brought down into the scrotum by mobilization of the spermatic pedicle; spermatic vessel ligation is not done in any patient in this series.

The finding of blind-ending vas and vessels indicated vanishing testis and further exploration was not done after removal of the tissue at the termination of the vas and vessels. Orchidectomy was performed when the testis was atrophic. High testes in abdominal were brought down in the inguinal region as a first stage surgery.

\section{Results}

Thirtyfive patients with 36 impalpable testes undergone inguinal exploration. Patient age ranges from 8 months to 13 years of age. Mean age at exploration was 22 months with $54.28 \%$ of the procedure done at the age below one year. Left sided was in $25(71.42 \%)$, right side $9(25.71 \%)$ and $1(2.85 \%)$ bilateral. At exploration, $17(47.22 \%)$ testes were located in inguinal canal, $9(25 \%)$ were intraabdominal and 4 were in scrotum. There were six cases with absence of testes.

Seven(41.17\%) intracanalicular testes and all $9(100 \%)$ intraabdominal testes underwent orchidopexy. Among the intraabdominal 9, 2 highly located testes underwent $1^{\text {st }}$ stage orchidopexy with mini-laparotomy by lateral extension of the incisional incision. 10(58.82\%) canalicular and $4(100 \%)$ scrotal testes diagnosed as atrophied, hypoplastic or nubbin underwent orchidectomy. In 6 cases a blind ending vas and vessels were identified and diagnosed monarchia and no further exploration done.

Post-operative period of one week to three months was available for review. Excellent result was a testis in proper scrotal position and size. Acceptable result was a palpable normal sized testes in high scrotum. In follow-up, 14 (87.5\%) orchidopexy patients had excellent result. One high intrabdominal testes with post first stage orchidopexy and one canalicular testes were found to have atrophied in follow up and orchidectomy was done. 
Table 1: Age distribution of study population

\begin{tabular}{lcc}
\hline Age range (months) $\mathbf{m}$ & $\begin{array}{c}\text { No of } \\
\text { patients }\end{array}$ & $\begin{array}{c}\text { Percentage } \\
(\%)\end{array}$ \\
\hline $6 \sim 12 \mathrm{~m}$ & 19 & 54.28 \\
\hline $12 \sim 24 \mathrm{~m}$ & 11 & 31.42 \\
\hline $24 \sim 36 \mathrm{~m}$ & 1 & 2.85 \\
\hline $36 \sim 48 \mathrm{~m}$ & 2 & 5.71 \\
\hline $48 \sim 60 \mathrm{~m}$ & 0 & 0 \\
\hline $60 \mathrm{~m} \sim 13$ yrs. & 2 & 5.71 \\
\hline Total & 35 & 100 \\
\hline
\end{tabular}

Table 2: Location of testes

\begin{tabular}{lcc}
\hline Site & No of testes & Percentage \\
\hline Left & 25 & 71.42 \\
\hline Right & 9 & 25.71 \\
\hline Bilateral & $1+1$ & 2.85 \\
Total & $\mathbf{3 6}$ & $\mathbf{1 0 0}$ \\
\hline
\end{tabular}

Table 3: Location of testes during exploration

\begin{tabular}{lcc}
\hline Location of testes & No of testes & Percentage (\%) \\
\hline Inguinal canal & 17 & 47.22 \\
\hline Intraabdominal & 9 & 25 \\
\hline Scrotum & 4 & 11.11 \\
\hline Absent & 6 & 16.66 \\
\hline Total & $\mathbf{3 6}$ & $\mathbf{1 0 0}$ \\
\hline
\end{tabular}

Table 4: Types of surgery performed

\begin{tabular}{lcc}
\hline $\begin{array}{l}\text { Type of surgery with } \\
\text { inguinal exploration }\end{array}$ & No of testes & Percentage \\
\hline Orchideopexy & 14 & 38.88 \\
\hline Gonadectomy & 14 & 38.88 \\
\hline Exploration only & 6 & 16.66 \\
\hline $1^{\text {st }}$ stage orchidopexy & 2 & 5.55 \\
\hline Total & $\mathbf{3 6}$ & $\mathbf{1 0 0}$ \\
\hline
\end{tabular}

Table 5: Type of surgery in relation to location of testes

\begin{tabular}{lccccc}
\hline \multirow{2}{*}{ Type of surgery } & \multicolumn{4}{c}{ Location of testes } & \multirow{2}{*}{ Total } \\
\cline { 2 - 5 } & Canal & Abdominal & Scrotal & Absent & \\
\hline Orchidopexy & $7(41.17 \%)$ & 7 low $(77.77 \%)$ & - & - & $14(38.88 \%)$ \\
\hline Gonadectomy & $10(58.82 \%)$ & - & $4(100 \%)$ & - & $14(38.88 \%)$ \\
\hline Exploration only & - & - & - & 6 & $6(16.66 \%)$ \\
\hline 1st stage orchidopexy & - & 2 high $(22.22 \%)$ & - & - & $2(5.55 \%)$ \\
\hline Total & $\mathbf{1 7 ( 4 7 . 2 2 \% )}$ & $\mathbf{9 ( 2 5 \% )}$ & $\mathbf{4 ( 1 1 . 1 1 \% )}$ & $\mathbf{6 ( 1 6 . 6 6 \% )}$ & $\mathbf{3 6 ( 1 0 0 \% )}$ \\
\hline
\end{tabular}

\section{Discussion}

An impalpable testis represents a complex diagnostic and therapeutic challenge to paediatric surgeon because it is difficult to know the position of the impalpable testis preoperatively by radiological and digital examination. The benefit of radiological investigation in this group of patients with impalpable testes remains controversial. Despite the availability of many options now, it is still commonly believed that none of them can accurately evaluate the position or morphology of the testis, with an estimation of $44 \%$ overall accuracy of these radiological investigations $\mathbf{s}^{3,4,5}$.

There are four possible reasons why the testes are not palpable. First the testes may be situated in the scrotum or inguinal canal but they are very small and there is too much subcutaneous adipose tissue. Second, the open processus vaginalis leading the testes to be in inguinal and intraabdominal position intermittently. Third it is in a true abdominal position and fourth the testes are absent ${ }^{6,7}$.

Consideration must be given as to whether the testis is absent or not. Exploration is indicated because retained impalpable testes constitute a significant risk to the patient from mortality secondary to malignant degeneration ${ }^{8}$. Therefore when inguinal exploration does not confirm an impalpable testis, retroperitoneal and/or intraperitoneal exploration is advisable. There is no commonly accepted management protocol regarding when and how to operate according to the position of the testis.

The age at operation is also an important factor to bring the testis successfully to the scrotum for the good outcome. It has been reported that early orchidopexy results in a significantly larger testicular volume at follow-up after 12 months, if the operation is performed at age nine months compared to three years ${ }^{9}$ A recent Scandinavian consensus report on treatment of undescended testes recommends orchidopexy before age one year to preserve spermatogenesis ${ }^{10}$. Our series support this where 11 out of $16(68.75 \%)$ impalpable testes undergone orchidopexy under the age of one year with good outcome in early follow-up.

Sixteen $(45.71 \%)$ patients in our study were operated over 12 months of age. Several reasons 
behind this are late referral from our general practitioner paediatrician, geographical situation, and long surgical waiting lists and in some other more important chronic diseases being treated first.

Twentyone impalpable testes in our series were located distal to the internal inguinal ring at exploration. True intra-abdominal testis was only nine among which two were in high and seven low abdominal position. The question arises whether performing routine laparoscopy would have been beneficial or not in this group of patients with impalpable testes in our series. Godbole et al in a recent study reviewed the place of laparoscopy for the impalpable testis. They found that by performing a laparoscopy they would have avoided a negative exploration in $42 \%$ of cases ${ }^{11}$. Our study has shown that performing a routine laparoscopy in all cases of impalpable testes leads unnecessary laparoscopies, because all of our impalpable testes were localized through an inguinal and trans-peritoneal exploration incision with only two high intraabdominal cases with extension as a mini-laparotomy. Laparoscopy only allows the surgeon to identify and manipulate the testes found above the internal ring. A dilemma arises when no testes are seen and vas and vessels exiting the ring ${ }^{12,13}$. Twentyone $(58.33 \%)$ of our cases had testes out of internal ring. Therefore laparoscopy would have been unnecessary in them. Chandrasekharam in his study could not show any advantage of routine laparoscopy over inguinal exploration in patient with impalpable testes $^{14}$

Six cases with anorchia would have been benefitted by laparoscopy but still they all were diagnosed with a small inguinal approach. Two of our high intraabdominal testes which were done $1^{\text {st }}$ stage orchidopexy would have also benefitted but only in regard to extended inguinal scar. Kirsch et. al. reported a large experience with 447 non-palpable testes, all of which were treated through a standard inguinal incision. They concluded that inguinal approach with trans-peritoneal mobilization of vas and vessels is highly successful for the intraabdominal testes $^{3}$. Williams et. al. reported that in 37 of impalpable testes, inguinal exploration was sufficient for deciding and executing treatment ${ }^{15}$. Adam and Allaway reported good results with inguinal exploration followed by intraperitoneal approach for $110 \mathrm{impalpable} \mathrm{testes.} \mathrm{They}$ concluded that the advantage of laparoscopy could be achieved by this simple surgery with a favourable cost: benefit ratio ${ }^{16}$.

Gulanikar et al stated that laparoscopic examination for impalpable testis should be considered only when the disorder cannot be diagnosed by inguinal exploration ${ }^{17}$. Our study also support their opinion and advise to perform diagnostic laparoscopic examination only when an impalpable testis is not identified under vision during the inguinal exploration. Laparoscopy increases operative time, anaesthesia time and cost without any significant advantage over open inguinal exploration ${ }^{19,20,21}$.

Inguinal canal in children differs from that in adults. It is clearly shorter, lies in a less oblique plane running in a more anteroposterior direction, and the tissues involved are more elastic. Also the skin and subcutaneous tissues are thinner and more mobile. These paediatric factors allow a degree of surgical freedom of movement and visualization in inguinal with trans-peritoneal exploration for impalpable testes ${ }^{18,2,22}$. This muscle splitting extraperitoneal approach has a low morbidity, allows post-operative regional anaesthesia and a short hospital stay. This technique also preserves the integrity of the inguinal canal. This technique allows optimal exposure of the testes and its blood supply achieving successful orchidopexy ${ }^{23,24}$. Our experience with inguinal approach with intraperitoneal/extraperitoneal exploration made us in conclusion that impalpable testes can be mobilized and brought into the scrotum successfully and safely with excellent results without any procedure related complications.

\section{Conclusion}

Our clinical experience of inguinal approach for the management of impalpable undescended testes is sufficient to mobilize and brought the testes down to scrotum safely with excellent postoperative results.

\section{References}

1. Hueih-ShingHsu. Management of boys with nonpalpable undescended testes. J Urol 2012;23(4):103-106. doi: http://dx.doi.org/10.1016/j. urols.2012.10.005.

2. Hutson JM, Clarke MC. Current management of the undescended testicle. Semin Pediatr Surg 2007;16(1):64-70. doi: 10.1053/j. sempedsurg.2006.10.009.
3. Kirsch AJ, Escala J, Duckett JW,Smith GH, Zderic SA,Canning DA and Synder HM. Surgical management of the nonpalpable testis: The Children's hospital of Philadelphia Experience. J Urol 1998;159:1340-343.

4. Kanemoto K, Hayashi $\mathrm{Y}$, Kojima $\mathrm{Y}$, Maruyama T, Ito $\mathrm{M}$, Kohri $\mathrm{K}$. Accuracy of ultrasonography and magnetic resonance imaging in the diagnosis of nonpalpable testis. Int J Urol 2005;12(7): 668-72. doi: 10.1111/j.1442-2042.2005.01102.x 
5. Sigrid M. P. Nijs, Sebastiaan W. Eijsbouts, Gerard C. Madern, Paul M. M. Leyman, Maarten H. Lequin and Frans W. J. Hazebroek. Nonpalpable testes: is there a relationship between ultrasonographic and operative findings? Pediatr Radiol 2007;37(4):374-379. Doi: 10.1007/s00247-007-0425-1

6. Gearhart JP, Jeffs RD. Diagnostic maneuvers in cryptorchidism. Semin Urol 1988;6(2):79-83.

7. Piet RH Callewaert, Mohammad S. Rahnama'i, Bart T. Biallosterski, Philip EV van Kerrebroeck. Scrotal Approach to Both Palpable and Impalpable Undescended Testes: Should It Become Our First Choice? Urology 2010;76(1):73-77. doi: 10.1016/j. urology.2009.09.096

8. Cortes D, Thorup JM, Visfeldt J. Cryptorchidism: aspects of fertility and neoplasms. A study including data of 1,335 consecutive boys who underwent testicular biopsy simultaneously with surgery for cryptorchidism. Horm Res 2001;55(1):21-7. https : // doi.org/10.1159/000049959

9. Kollin C, Karpe B, Hesser U, Granholm T, Ritzen EM. Surgical treatment of unilaterally undescended testes: testicular growth after randomization to orchiopexy at age 9 months or 3 years. $J$ Urol 2007;178(4Pt2):158993. doi:10.1016/j.juro.2007.03.173.

10. Ritzén EM, Bergh A, Bjerknes R, Christiansen P, Cortes $D$, Haugen SE et. al. Nordic consensus on treatment of undescended testes. Acta Paediatr 2007;96(5):63843. doi:10.1111/j.1651-2227.2006.00159.x

11. Godbole PP, Morecroft JA. Laparoscopy for the impalpable testis. Br J Surg 1997;84(10):1430-432. doi: 10.1111/j.1365-2168.1997.02817.x

12. Heiss KF and Shandling B. Laparoscopy for the Impalpable Testes: Experience with 53 Testes. J Pediatr Surg 1992;27(2):175-78.

13. Gouda Mohamed El-labban. Laparoscopic versus Open Orchiopexy Approach for the Management of Non-Palpable Undescended Testis. JPSS 2013;7(4):18-23.

14. Chandrashekharan VV. Laparoscopy vs inguinal exploration for nonpalpable undescendent testes. Indian J Pediatr. 2005;72(12):1021-23.
15. Williams EV, Appanna T, Foster ME. Management of the impalpable testes. A six year review together with a national experience. Postgrad Med J 2001;77(907):320-322. doi: http : //dx.doi.org/10.1136/ pmj. 77.907 .320

16. Adam AS, Allaway AJ. The difficult orchidopexy: the value of the abdominal pre-peritoneal approach. BJU Int 1999;83(3):290-93.

17. Gulanikar AC, Anderson PA, Schwarz R, Giacomantonio M. Impact of diagnostic laparoscopy in the management of the unilateral impalpable testis. $\mathrm{Br}$ J Urol 1996;77(3):455-57.

18. Kanemoto $\mathrm{K}$ et al. The management of of nonpalpable testes with combined groin exploration and subsequent transinguinal laparoscopy. J Urol 2002;167;674-76. doi: http : //dx.doi.org/10.1016/S0022-5347(01)691225.

19. Singh RR, Rajimwale A, Nour S. Laparoscopic management of impalpable testes :comparison of different techniques. Pediatr Surg Int 2011;27(12):132730. doi: 10.1007/s00383-011-2970-9

20. Argos Rodriguez MD, Unda Freire, Ruiz OrpezA, Garcia Lorenzo C. Diagnostic and therapeutic laparoscopy for nonpalpable testis. Surg Endosc 2003;17(11):1756758. doi: $10.1007 / \mathrm{s} 00464-002-8592-5$

21. Bae KH, Park JS, Jung HJ, Shin HS. Inguinal approach for the management of unilateral non-palpable testis : Is diagnostic laparoscopy necessary?. J Pediatr Urol 2014;10(2):233-236. doi: http : //dx.doi.org/10.1016/j. jpurol.2013.09.022

22. Youngson GG and Jones PF. Management of the Impalpable Testis: Long-Term Results of the Preperitoneal Approach. $J$ Pediatr Surg 1991;26(5):618-20. doi: http : //dx.doi. org/10.1016/0022-3468(91)90722-6.

23. Bianchi A. Management of the impalpable testis, the role of microvascular orchidopexy. Pediatr Surg Int 1990;5(1):48-53.

24. King LR. Orchiopexy for impalpable testis: high spermatic vessel division is a safe maneuver. $J$ Urol 1998;160(6Pt 2):2457-460. 